\title{
The influence of lean-oriented team performance management practices on lean service requirements
}

\author{
Wojciech Ulrych \\ University of Łódź, Faculty of Management
}

\section{Introduction}

Lean methodology is known for its process-oriented, value-stream mapping approach, in order to decrease all kinds of waste and to allow smoother team based workflow in a never-ending drive towards perfection ${ }^{1}$. Bear in mind that no teamwork should ever be the cause of waste. Teamwork is necessary when a lean service is introduced, when a $5 \mathrm{~S}$ tool is put into practice or when kaizen workshops are organized ${ }^{2}$. However, it is not clear which lean-oriented teamwork practices can be universally observed with regards to typical team performance management (TPM) as presented by Armstrong and Aguinis ${ }^{3}$. When introducing teamwork, many western managers would like to emulate what they perceive to be as a source of advantage in other cultures, just like it is in Japanese firms 4 . As a matter of fact we can distinguish some of the aforementioned practices within process-oriented teams, kaizen workshops

1 A. Chiarini, Lean Organization: from the Tools of the Toyota Production System to Lean Office, Springer-Verlag Italia, Milan - Heidelberg - New York - Dordrecht - London 2013; D. Locher, Lean Office and Service Simplified, CRC Press, Taylor and Francis Group, Boca Raton 2011.

2 A. Chiarini, Lean Organization ...; D. Locher, Lean Office ...; D. Tapping, The lean office pocket guide. Tools for the elimination of waste in the administrative areas, MCS Media Inc., Chelsea 2005.

3 M. Armstrong, Armstrong's handbook of performance management. An evidence-based guide to delivering high performance, Kogan Page, New York 2015; H. Aguinis, Performance management, Pearson/Prentice Hall International, Harlow 2009.

4 C. Atkinson, S. Shaw, Managing performance, [in:] R. Lucas, B. Lupton, H. Mathieson (eds), Human Resource Management in an International Context, Chartered Institute of Personnel and Development, London 2006, p. 182. 
or within quality circles. However, there is still little research on how team performance management (TPM) works at all 5 . Interestingly, employee performance management (EPM) is broadly presented in the HRM-oriented Polish literature and used in practice as a result of cultural individualism in Poland. Lean methodology goes against such typical EPM practices.

The aim of this paper is to present the current literature and the author's findings regarding the influence of lean-oriented TPM practices on lean service (LS) requirements within Polish service departments. In order to do this there was a need to identify how lean-oriented teamwork practices reflect the practices and stages of the universal TPM model as presented by Armstrong and Aguinis ${ }^{6}$. It also highlights the importance of EPM practices in lean-based TPM activities.

\section{Team performance management (TPM) practices and lean-oriented teamwork}

Performance management (PM) is a "continuous process of identifying, measuring, and developing the performance of individuals and teams and aligning performance with the strategic goals of the organization"7. PM refers to the range of activities engaged in by an organization to enhance the performance of a target person or group, with the ultimate purpose of improving organizational effectiveness $^{8}$. It involves performance reviews focusing on the future rather than the past ${ }^{9}$. The integration of performance levels (individual, team and organizational) means that team performance management also has an impact on the level of individual performance and on the level of organizational effectiveness ${ }^{10}$. In other words,

\section{Ibidem.}

6 M. Armstrong, Armstrong's handbook...; H. Aguinis, Performance...

7 H. Aguinis, Performance..., p. 3.

8 A.S. DeNisi, Performance appraisal and performance management: a multilevel analysis, [in:] K.J. Klein, S.W.J. Kozlowski (eds), Multilevel theory, Research and Methods in Organizations, Jossey-Bass, San Francisco 2000, pp. 121-156; also see D.N. Den Hartog, P. Boselie, J. Paauwe, Performance management; a model and research agenda, "Applied Psychology: An International Review" 2004, vol. 53, no. 4, pp. 556-569.

9 D.N. Den Hartog, P. Boselie, J. Paauwe, Performance management...

10 M. Armstrong, Armstrong's handbook...; J. Shields, Managing employee performance and reward. Concepts, Practices, Strategies, Cambridge University Press, Cambridge 2007; A. Pocztowski, Zarządzanie zasobami ludzkimi. Strategie, procesy, metody, Polskie Wydawnictwo Ekonomiczne, Warszawa 2008, p. 252; S. Borkowska, Strategie wynagrodzeń, Oficyna Ekonomiczna, Kraków 2001, p. 195; G.B. Brumback, Blending the "we/me" in performance management, "Team Performance Management: An International Journal” 2003, vol. 9, no. 7/8, pp. $167-173$. 
there is a need to measure and manage the performance of individual employees in the hope of ultimately influencing the performance of the team or the entire organization ${ }^{11}$. It is worth noting that the TPM literature presents a few stages of the aforementioned process as a continuous process with team and individual development activities at its core ${ }^{12}$. Each stage consists of a few practices and if they are all set together in the correct order then they can influence the team's level of performance (Table 1).

Table 1. A typical set of TPM practices versus in-service lean-oriented teamwork practices with regards to the TPM stages

\begin{tabular}{|c|c|c|}
\hline Stages & TPM practices & $\begin{array}{c}\text { In-service lean-oriented teamwork } \\
\text { practices }\end{array}$ \\
\hline Prerequisite & $\begin{array}{l}\text { - job descriptions } \\
\text { - competencies needed to fulfill } \\
\text { responsibilities }\end{array}$ & $\begin{array}{l}\text { - process-oriented documents, } \\
\text { i.e. Value Stream Mapping (VSM) } \\
\text { competencies/behaviors } \\
\text { to cater for process needs } \\
\text { - lean requirements preparation, } \\
\text { e.g. visual management and } \\
\text { control }\end{array}$ \\
\hline $\begin{array}{l}\text { Planning team } \\
\text { performance }\end{array}$ & $\begin{array}{l}\text { - } \text { setting objectives and tasks } \\
\text { merformance outcome and } \\
\text { measures (i.e. Key Performance } \\
\text { Indicators, KPIs) } \\
\text { - both individual and team } \\
\text { performance improvement and } \\
\text { development plans }\end{array}$ & $\begin{array}{l}\text { - setting objectives and tasks } \\
\text { by using the hoshin kanri } \\
\text { process (i.e. keeping up with } \\
\text { work standards, competency } \\
\text { improvements) } \\
\text { - KPIs e.g. Lead Time; \% of JiT } \\
\text { tasks, OPE indicators } \\
\text { - avoiding measures of individual } \\
\text { performance } \\
\text { - team } 5 \text { S audit plans } \\
\text { - no. of innovations/ideas } \\
\text { in terms of process performance } \\
\text { improvements } \\
\text { - team performance } \\
\text { improvement by the usage } \\
\text { of PDCA tool }\end{array}$ \\
\hline
\end{tabular}

11 A.S. DeNisi, Performance appraisal..., p. 123; D.N. Den Hartog, P. Boselie, J. Paauwe, Performance management...

12 M. Armstrong, Armstrong's handbook...; H. Aguinis, Performance...; D.N. Den Hartog, P. Boselie, J. Paauwe, Performance management... 
Table 1 (continued)

\begin{tabular}{|c|c|c|}
\hline Stages & TPM practices & $\begin{array}{l}\text { In-service lean-oriented teamwork } \\
\text { practices }\end{array}$ \\
\hline $\begin{array}{l}\text { Executing/Supporting } \\
\text { team performance }\end{array}$ & $\begin{array}{l}\text { - team/individual performance } \\
\text { monitoring done by individuals } \\
\text { and/or conducted by a manager } \\
\text { - feedback transmitted between } \\
\text { individuals and from a manager } \\
\text { - self-assessment } \\
\text { - coaching from a manager }\end{array}$ & $\begin{array}{l}\text { - process-based team/individual } \\
\text { performance monitoring } \\
\text { of "what is being done" (i.e. } \\
\text { quick standards review or how } \\
\text { lean tools are used in practice) } \\
\text { done by individuals and/ } \\
\text { or conducted by a manager } \\
\text { (during gemba walking) } \\
\text { - individual performance } \\
\text { coaching from a manager } \\
\text { (during gemba walking to solve } \\
\text { work problems; kaizen process) } \\
\text { - feedback transmitted between } \\
\text { individuals and from a manager } \\
\text { and team (employees moved } \\
\text { around the process where } \\
\text { needed) }\end{array}$ \\
\hline $\begin{array}{l}\text { Assessing/Reviewing } \\
\text { team performance }\end{array}$ & $\begin{array}{l}\text { - team performance assessment } \\
\text { of "what was done" conducted } \\
\text { by a manager; peer input } \\
\text { assessment } \\
\text { - team performance review } \\
\text { of "how it was done" conducted } \\
\text { by the team during a meeting } \\
\text { with a manager } \\
\text { - self-assessment } \\
\text { - individual performance review } \\
\text { and assessment done during } \\
\text { a meeting with a manager }\end{array}$ & $\begin{array}{l}\text { - process-based team } \\
\text { performance assessment } \\
\text { of "what was done" conducted } \\
\text { by a manager } \\
\text { - no individual performance } \\
\text { assessment }\end{array}$ \\
\hline
\end{tabular}

Source: own study based on: M. Armstrong, Armstrong's handbook of performance management. An evidence-based guide to delivering high performance, Kogan Page, New York 2015; H. Aguinis, Performance management, Pearson/Prentice Hall International, Harlow 2009; A. Chiarini, Lean Organization: from the Tools of the Toyota Production System to Lean Office, SpringerVerlag Italia, Milan - Heidelberg - New York - Dordrecht - London 2013; M. Imai, Gemba kaizen. Zdroworozsqdkowe podejście do strategii ciqgłego rozwoju, Wydawnictwo MT Biznes, Warszawa 2018; J.K. Liker, K. Ross, Droga Toyoty do doskonałości w usługach, Wydawnictwo MT Biznes, Warszawa 2018; J.K. Liker, G.L. Convis, Droga Toyoty do lean leadership, Wydawnictwo MT Biznes, Warszawa 2012; D. Locher, Lean Office and Service Simplified, CRC Press, Taylor and Francis Group, Boca Raton 2011; D. Tapping, The lean office pocket guide. Tools for the elimination of waste in the administrative areas, MCS Media Inc., Chelsea 2005.

The cycle of TPM stages is similar to its employee/individual performance management counterpart (EPM). It shows a close relationship of practices between TPM and EPM, although there are some constraints in building the bridge between these levels of performance. Brumback points out that managing individual and team performance meets the challenge of blending individualism with teamwork. 
Parties that play their roles in TPM include individuals, the team and a manager who is more coach than judge ${ }^{13}$.

Bearing the above in mind we can highlight the lean-oriented teamwork practices found in the lean literature, which reveals that they have their counterparts in the typical TPM stages (Table 1). This is why they can be developed in the form of lean-oriented TPM.

Toyota doesn't believe in autonomous teams or lean groups without strong leadership $^{14}$. Line management is responsible for objectives regarding work quality, costs, delivery and kaizen for workers at their workstations ${ }^{15}$. Locher's remarks on leadership in a lean service are helpful to single lean-oriented teamwork practices out ${ }^{16}$. He lists driving continuous improvement (Plan-Do-Check-Act - PDCA), delivering mentoring, gemba walking (i.e. to the workstation), performance measurement and recognition. Liker and Convis point out that a team leader is responsible for achieving and coordinating objectives (i.e. hoshin kanri) and everyday kaizen (continuous improvements) ${ }^{17}$. The team leader can influence team individuals, coordinate and monitor team objectives and coach workers. Building employee - team leader trust is key.

As far as the prerequisite stage is concerned preparing visual management and control principles becomes absolutely vital for the manager and workers in the industry, e.g. when it comes to the next stage of planning goals and tasks with regards to appointments between sales workers and customers ${ }^{18}$. It is also helpful to monitor appointments by simply crossing them off from the noticeboard. However, transactions are often hard to visualize. Chiarini also points out that Overall Professional Effectiveness (OPE) and its three indicators which includes availability, efficiency and quality can be adapted to the lean service ${ }^{19}$. Many other performance indicators regarding lean requirements can be met, including lead time, percentage execution of JiT (Just-in-Time), etc.

Supporting team performance is represented by a wide span of lean practices. Training Within Industries (TWI) is usually conducted by a superior and aims to improve the process by making the best use of people, equipment, materials,

13 G.B. Brumback, Blending...

14 J.K. Liker, K. Ross, Droga Toyoty do doskonatości w ustugach, Wydawnictwo MT Biznes, Warszawa 2018, p. 423.

15 M. Imai, Gemba kaizen. Zdroworozsqqdkowe podejście do strategii ciqggłego rozwoju, Wydawnictwo MT Biznes, Warszawa 2018, p. 55.

16 D. Locher, Lean Office..., p. 131.

17 J.K. Liker, G.L. Convis, Droga Toyoty do lean leadership, Wydawnictwo MT Biznes, Warszawa 2012, p. 178.

18 A. Chiarini, Lean Organization...

19 Ibidem, p. 151. 
etc. ${ }^{20}$ Leaders in a lean organization can coach, counsel, guide and tutor an employee. Such mentoring often occurs during one-to-one interactions between the leader and an individual21, by the usage of step-by-step improvements ${ }^{22}$.

According to Locher assessing team performance means using team-based measures of a single process whilst avoiding measures of individual performance due to lean requirements ${ }^{23}$. As a consequence, there is no room for job descriptions, individual performance appraisal or pay for individual performance ${ }^{24}$.

In spite of the many doubts about lean being used in the service sector, many organizations have already introduced this methodology 25 , which derives from the lean requirements briefly presented in Table 4 .

\section{Methodology, findings and hypothesis verification}

The research aim of this paper is to develop, verify and analyze the findings of a model which will reveal grouped sets of lean-oriented TPM practices, presented in the form of factors which influence lean service (LS) requirements. In order to do this there was a need to identify such lean-oriented teamwork practices that have their counterpart in the universal TPM process (Table 1). It is also worth highlighting that lean-oriented TPM practices still have much to do with practices regarding individual EPM.

Based on the aforementioned remarks we have four key research questions:

1. "Which sets of practices regarding lean-oriented teamwork can be grouped into mutually supporting factors?";

2. "Do these groups of factors refer to the stages of the typical TPM model approach presented by Armstrong and Aguinis?";

3. "Do the requirements regarding a LS form a single factor?";

4. "What is the impact of lean-oriented TPM factors on the LS factor?".

20 D. Locher, Lean Office..., p. 134.

21 Ibidem, p. 137.

22 R. Maurer, Filozofia kaizen. Małymi krokami ku doskonałości, Wydawnictwo Helion, Gliwice 2016.

23 D. Locher, Lean Office..., p. 140.

24 J.P. Womack, Why are rewards tied to individual performance so dangerous?, https://planet-lean.com/womack-rewards-metrics-yokoten/ (accessed: 7.07.2019); W.J. Rothwell, J. Graber, N. McCormick, Lean but Agile: Rethink Workforce Planning and Gain a True Competitive Edge, Amacom, American Management Association, New York 2012, pp. 146-147; J.K. Liker, G.L. Convis, Droga Toyoty..., p. 219; D. Locher, Lean Office...

25 J.C. Chen, R.A. Cox, Value Stream Management for Lean Office - A Case Study, "American Journal of Industrial and Business Management" 2012, no. 2, pp. 18-21; J.K. Liker, K. Ross, Droga Toyoty... 
With these questions in mind the following five hypotheses were developed:

H1: Lean-oriented TPM factors are similar in comparison to those stages presented in the literature models by Armstrong and Aguinis.

$\mathrm{H} 2$ : There are employee-oriented TPM factors.

H3: TPM factors as a whole influence the LS factor.

H4: There are some independent TPM factors that affect the LS requirements regardless of other factors.

H5: The number of years of lean influences the TPM-LS relationship.

The method used in creating factors is exploratory factor analysis (EFA) by generalized least squares (GLS) and Kaiser's normal varimax rotation. The application of this method was dictated by the use of secondary data (the author's database for the needs of verification of the impact of EPM on LS). By isolating the factors, the same method was always used throughout the paper. Based on Table 1 a set of in-service lean-oriented teamwork practices was chosen from a database regarding lean-oriented TPM practices (18 items; Table 2 and 3 ) as well as lean requirements ( 7 items; Table 4). The EFA method helped to group items into entities known as "factors". The development of factors for the model was carried out using IBM SPSS Statistics.

Database includes $n=173$ purposefully selected Polish service departments in terms of the following criteria: service delivery and identification of lean requirements by managers of these departments in terms of principles, methods, tools and lean measures. The analyzed departments included support for the production process (i.e. maintenance, forwarding, logistics, 28.9\%), as well as departments providing services to internal and external clients ( $\mathrm{HR}$, accounting and finance, purchasing, quality control, customer service, R\&D and lean, 57.22\%) and "other" service departments (13.87\%). A 5 point rating scale was used in the questionnaire.

Out of 13 questions (Table 2) 4 factors were developed and isolated for lean-oriented TPM practices (C1, C2, C3, C4). Not all of them were used in building the factors. A few items were removed: p5.6, p14.1, p16.3 and 17.1 because they have less than 0.3 of common volatility (it should be over 0.3 ).

Table 2. Lean-oriented TPM practices

\begin{tabular}{|l|l|}
\hline Items & \multicolumn{1}{|c|}{ Descriptions } \\
\hline p2.2 & $\begin{array}{l}\text { Goals and tasks for the next work period have repeatable standards in terms } \\
\text { of behavior or quality of work }\end{array}$ \\
\hline p2.3 & Goals and tasks for the next work period are set for the whole team \\
\hline p2.4 & $\begin{array}{l}\text { Goals and tasks for the next period are consistent with the job description or other } \\
\text { workstation instructions }\end{array}$ \\
\hline p2.8 & $\begin{array}{l}\text { The achievement of goals and tasks for the next period are measured with } \\
\text { performance indicators }\end{array}$ \\
\hline
\end{tabular}


Table 2 (continued)

\begin{tabular}{|l|l|}
\hline Items & \multicolumn{1}{c|}{ Descriptions } \\
\hline p5.2 & $\begin{array}{l}\text { The manager monitors the goals, progress and reviews the achievements of the entire } \\
\text { team }\end{array}$ \\
\hline p5.5 & The manager provides feedback to the entire team during meetings \\
\hline p5.6 & $\begin{array}{l}\text { The manager uses applications and mobile tools in the process of monitoring and } \\
\text { reviewing achievements }\end{array}$ \\
\hline p7.15 & Team achievements only count \\
\hline p7.16 & Individual assessment is a component of team performance \\
\hline p14.1 & $\begin{array}{l}\text { There are multi-functional teams known as "nests" or “linear work offices" in which } \\
\text { employees perform tasks of a different nature }\end{array}$ \\
\hline p16.3 & To ensure all rules and regulations are adhered to, a periodic audit is necessary \\
\hline p17.1 & $\begin{array}{l}\text { The team meets regularly and works on implementing improvements in a given area } \\
\text { of the organization's activity }\end{array}$ \\
\hline p17.9 & $\begin{array}{l}\text { The goals of continuous improvement are visible to the team and take a visual form, } \\
\text { e.g. a worksheet, a table containing problems, etc. }\end{array}$ \\
\hline
\end{tabular}

Source: based on the author's own research.

The EFA methodology needs to call the factors:

- $\mathrm{C} 1$ - p2.8, p17.9 - prerequisite phase;

- $\mathrm{C} 2$ - p2.2 and p2.3, p 2.4 - planning team performance;

- C3 - p5.2 and p5.5 - supporting team performance;

- C4 - p7.15 and p7.16 - both individual and team performance assessment.

Statistics on the correctness of factor creation:

- Kaiser-Meyer-Olkin (KMO) Test for Sampling Adequacy = 0.713 and confirms that the grouping of these items is correct (should be over 0.5);

- Bartlett's test of sphericity: chi square $=333.562$;

- Degrees of freedom $(D f)=66$;

- P-value $=0.000, p<0.05$;

- The correlation matrix has all values greater than 0.5 on the main diagonal, which indicates the adequacy of the sample selection.

The findings at this stage point out that the lean-oriented TPM factors (C1, C2, C3, $\mathrm{C} 4)$ represents a typical set of TPM stages. However, the prerequisite phase (C1) includes indicators and visual solutions of the goals and tasks to be planned in the next stage (factor C2, i.e. planning performance). Supporting team performance (factor C3) is part of the manager's domain. In turn, the assessment stage (factor C4) joins together employee and team performance assessment. Bear in mind that assessing individual performance goes against lean methodology. Each factor represents 2-3 practices.

Out of 5 questions (Table 3) 2 factors were developed and isolated for employeeoriented TPM (I1 and I2). 
Table 3. Employee-oriented TPM practices

\begin{tabular}{|l|l|}
\hline Items & \multicolumn{1}{|c|}{ Descriptions } \\
\hline p2.6 & Goals and tasks for an individual employee are determined with the help of the team \\
\hline p3.4 & $\begin{array}{l}\text { An individual performance improvement plan is developed with the support of the } \\
\text { team }\end{array}$ \\
\hline p6.1 & $\begin{array}{l}\text { The team monitors and acts as a coach and helps to solve problems related } \\
\text { to individual performance }\end{array}$ \\
\hline p6.2 & $\begin{array}{l}\text { The team provides an ongoing feedback to the employee about his individual } \\
\text { performance }\end{array}$ \\
\hline p7.10 & Individual performance assessment is carried out by a team \\
\hline
\end{tabular}

Source: based on the author's own research.

The EFA methodology needs to call the factors:

- I1 - p6.1, p6.2 - supporting individual performance;

- $\mathrm{I} 2$ - p2.6, p3.4, p7.10 - planning and assessing individual performance.

All questions were used in building the factors. Statistics on the correctness of factor creation are the following:

- Kaiser-Meyer-Olkin (KMO) Test for Sampling Adequacy = 0.682;

- Bartlett's test of sphericity: chi square $=154$. 788;

- Degrees of freedom $(D f)=10$;

- P-value $=0.000, p<0.05$;

- The correlation matrix has all values greater than 0.624 on the main diagonal. This stage of the findings shows the importance of TPM practices on the performance of individuals by giving feedback and monitoring (factor I1) and setting their objectives, and teaching and assessing performance (factor I2).

The items found in Table 4 are represented by statements regarding the most fundamental lean service requirements 26 : VSM, Kaizen, work standards, 5S, pull and push systems, and flow and visualization. They were also used to build the LEAN factor.

Table 4. Lean Service requirements - key statements

\begin{tabular}{|l|l|l|}
\hline Items & \multicolumn{1}{|c|}{ Descriptions } & \multicolumn{1}{|c|}{$\begin{array}{l}\text { Lean } \\
\text { requirements }\end{array}$} \\
\hline p18.1 & $\begin{array}{l}\text { The processing of information, documents or the provision of a service } \\
\text { is subordinated to the expectations of the final recipient and takes the } \\
\text { form of a value stream map for the customer }\end{array}$ & $\begin{array}{l}\text { Value Stream } \\
\text { Mapping } \\
\text { (VSM) }\end{array}$ \\
\hline p17.1 & $\begin{array}{l}\text { The team meets regularly and works on implementing improvements } \\
\text { in a given area of the organization's activity }\end{array}$ & Kaizen \\
\hline p12.1 & $\begin{array}{l}\text { There is a set sequence of activities for each task, its implementation } \\
\text { time, and other parameters that guarantee repeatability of the results } \\
\text { (documents, information, services) }\end{array}$ & $\begin{array}{l}\text { Work } \\
\text { standards }\end{array}$ \\
\hline
\end{tabular}

26 D. Locher, Lean Office... 
Table 4 (continued)

\begin{tabular}{|c|c|c|}
\hline Items & Descriptions & $\begin{array}{l}\text { Lean } \\
\text { requirements }\end{array}$ \\
\hline p16.1 & $\begin{array}{c}\text { Each employee regularly identifies and disposes of unnecessary } \\
\text { items on the station (e.g. materials, books), puts the necessary items } \\
\text { in marked places (e.g. in the described drawers), cleans and ensures } \\
\text { the safety of the workplace - performs these activities routinely and } \\
\text { in accordance with the standards }\end{array}$ & $5 S$ \\
\hline p15.2 & $\begin{array}{l}\text { Teams control the flow of resources using visual signals (e.g. } \\
\text { on noticeboards, using colors, labeling documents in the right way, } \\
\text { etc.) }\end{array}$ & Pull \\
\hline p14.3 & $\begin{array}{l}\text { In a multi-tasking environment, the employee knows "what" and } \\
\text { "when" to do (this is related to high predictability of work and its } \\
\text { schedule) }\end{array}$ & Flow \\
\hline p14.4 & $\begin{array}{l}\text { Visual tools are used (e.g. noticeboard for monitoring work progress } \\
\text { and results, signs, flags, computer applications, etc.) }\end{array}$ & $\begin{array}{l}\text { Work } \\
\text { visualization }\end{array}$ \\
\hline
\end{tabular}

Source: own study based on D. Locher, Lean Office...

Statistics on the correctness of the LEAN factor creation are as follows:

- Kaiser-Meyer-Olkin (KMO) Test for Sampling Adequacy = 0.806;

- Bartlett's test of sphericity: chi square = 251. 239;

- Degrees of freedom $(D f)=21$;

- P-value $=0.000, p<0.05$;

- The correlation matrix has all values greater than 0.755 on the main diagonal;

- Exploratory factor analysis shows that all 7 items form one factor, isolated here for lean service (called LEAN). The value of one of the items (p18.1) is 0.277 , but converges to 0.3 . and was considered to be proper in the factor.

Having developed all factors there is now a need to check how they all correlate with one another. Therefore, correlations between factors were examined. Table 5 shows two important points:

- firstly, all these factors statistically significantly correlate with each other and affect the LEAN factor, except for the C4 factor; lack of correlation between C4 and LEAN shows that there is no statistically significant relationship between both the team and individuals in terms of assessment practices (p7.15, p7.16) and the implementation of lean requirements (LEAN factor); similarly, the causal relationship between individual, team and organizational performance (implementation of LEAN requirements) is also postulated in the literature, although difficult to grasp in practice; however, there is a statistically significant correlation between lean-oriented TPM practices (C1, C2, C3, C4), applied practices of employee-oriented TPM (I1 and I2), and lean requirements (LEAN factor);

- secondly, the correlation between all factors translates the same information into LEAN factors. 
Table 5. Global correlation between highlighted factors $(n=173)$

\begin{tabular}{|c|l|l|l|l|l|l|l|l|}
\hline \multicolumn{2}{|c|}{ Correlations } & \multicolumn{1}{c|}{ C1 } & \multicolumn{1}{c|}{ C2 } & C3 & C4 & I1 & I2 & LEAN \\
\hline \multirow{2}{*}{ C1 } & Pearson's correlation & 1 & $.395^{\star \star}$ & $.303^{\star \star}$ & -.053 & $.293^{\star \star}$ & $.162^{\star}$ & $.655^{\star \star}$ \\
\cline { 2 - 9 } & Significance & & .000 & .000 & .245 & .000 & .017 & .000 \\
\hline \multirow{2}{*}{ C2 } & Pearson's correlation & $.395^{\star \star}$ & 1 & $.336^{\star \star}$ & $-.143^{\star}$ & $.197^{\star \star}$ & $.199^{\star \star}$ & $.420^{\star \star}$ \\
\cline { 2 - 9 } & Significance & .000 & & .000 & .031 & .005 & .004 & .000 \\
\hline \multirow{2}{*}{ C3 } & Pearson's correlation & $.303^{\star \star}$ & $.336^{\star \star}$ & 1 & -.004 & $.247^{\star \star}$ & $.231^{\star \star}$ & $.354^{\star \star}$ \\
\cline { 2 - 9 } & Significance & .000 & .000 & & .479 & .001 & .001 & .000 \\
\hline \multirow{2}{*}{ C4 } & Pearson's correlation & -.053 & $-.143^{\star}$ & -.004 & 1 & $.263^{\star \star}$ & $.389^{\star \star}$ & .032 \\
\cline { 2 - 9 } & Significance & .245 & .031 & .479 & & .000 & .000 & .337 \\
\hline \multirow{2}{*}{ I1 } & Pearson's correlation & $.293^{\star \star}$ & $.197^{\star \star}$ & $.247^{\star \star}$ & $.263^{\star \star}$ & 1 & $.357^{\star \star}$ & $.332^{\star \star}$ \\
\cline { 2 - 9 } & Significance & .000 & .005 & .001 & .000 & & .000 & .000 \\
\hline \multirow{2}{*}{ 12 } & Pearson's correlation & $.162^{\star}$ & $.199^{\star \star}$ & $.231^{\star \star}$ & $.389^{\star \star}$ & $.357^{\star \star}$ & 1 & $.244^{\star \star}$ \\
\cline { 2 - 9 } & Significance & .017 & .004 & .001 & .000 & .000 & & .001 \\
\hline \multirow{2}{*}{ LEAN } & Pearson's correlation & $.655^{\star \star}$ & $.420^{\star \star}$ & $.354^{\star \star}$ & .032 & $.332^{\star \star}$ & $.244^{\star \star}$ & 1 \\
\cline { 2 - 9 } & Significance & .000 & .000 & .000 & .337 & .000 & .001 & \\
\hline
\end{tabular}

*. Significant correlation at the 0.05 level (1-tailed).

${ }^{\star \star}$. Significant correlation at the 0.01 level (1-tailed).

Source: based on the author's own research.

Therefore, in order to determine the actual impact of each individual factor on LEAN, it was necessary to check which of the distinguished factors $(\mathrm{C} 1, \mathrm{C} 2, \mathrm{C} 3$, $\mathrm{C} 4$ and I1, I2) reflect the impact on the LEAN factor, according to a model built based on the regression function:

$$
\mathrm{L}=\mathrm{a} 1 \mathrm{C} 1+\mathrm{a} 2 \mathrm{C} 2+\mathrm{a} 3 \mathrm{C} 3+\mathrm{a} 4 \mathrm{C} 4+\mathrm{a} 5 \mathrm{I} 1+\mathrm{a} 6 \mathrm{I} 2+\mathrm{b},
$$

where:

L - factor LEAN,

$\mathrm{a} 1, \ldots, \mathrm{a} 6$ - parameter indicating the strength of influence,

$\mathrm{C} 1, \ldots, \mathrm{C} 4$ and I1, I2 - developed factors,

$\mathrm{b}$ - constant term.

To assess the impact of factors (C1, C2, C3, C4 and I1, I2) on LEAN, the significance of the model was assessed (Table 6). Other parameters of the model are the following: change in dependent variable by changes in independent variables R-square $=49.3 \%$, standard error of estimating the model $S=0.564$. Then the strength of the impact of each factor and its significance on the dependent LEAN variable was determined (Table 7). 
Table 6. Assessment of model significance of the factors impact on LEAN

\begin{tabular}{|l|c|c|c|c|c|}
\hline \multicolumn{1}{|c|}{ Anova $^{\mathrm{a}}$} \\
\hline Megression & Sum of squares & Degrees of freedom & Mean square & F-value & P-value \\
\hline Residuals & 51.415 & 6 & 8.569 & 26.883 & $.000^{\mathrm{b}}$ \\
\hline Total & 52.914 & 166 & .319 & & \\
\hline
\end{tabular}

a Dependent variable: lean.

b Predictors: (constant) C1, C2, C3, C4, I1, I2.

Source: based on the author's own research.

Table 7. Assessment of significance of model parameters

\begin{tabular}{|c|c|c|c|c|c|}
\hline \multirow{2}{*}{ Model } & \multicolumn{2}{|c|}{ Non-standardized coefficients } & \multicolumn{1}{c|}{$\begin{array}{c}\text { Standardized } \\
\text { coefficients }\end{array}$} & \multirow{2}{*}{$\mathrm{t}$} & Significance \\
\cline { 2 - 4 } & $\mathrm{B}$ & Standard error & Beta & & \\
\hline (Constants) & .898 & .317 & & 2.828 & .005 \\
\hline C1 & .361 & .043 & .528 & 8.398 & .000 \\
\hline C2 & .147 & .062 & .151 & 2.371 & .019 \\
\hline C3 & .114 & .064 & .108 & 1.771 & .078 \\
\hline C4 & .029 & .050 & .036 & .577 & .565 \\
\hline I1 & .065 & .045 & .090 & 1.435 & .153 \\
\hline I2 & .051 & .059 & .056 & .869 & .386 \\
\hline
\end{tabular}

Source: based on the author's own research.

The research results indicate that only two factors (C1 and C2), independently of each other and other factors, show the statistically significant influence on the LEAN factor with a strength of $\mathrm{C} 1=0.5$ and $\mathrm{C} 2=0.15$. Therefore, only (a) the prerequisite phase, i.e. performance indicators and goals and tasks visualization, and (b) planning performance in terms of the quality of work, standards and workstation instructions affect the implementation of LEAN requirements independently. Nevertheless bear in mind that correlation between all factors translates the same information into LEAN factors.

Based on the above findings the hypotheses were verified. In conclusions, hypotheses $\mathrm{H} 1$ and $\mathrm{H} 2$ were confirmed. They both show that in a lean-oriented TPM process there are still practices turned onto individuality and being similar to EPM process. Hypothesis H3 was not confirmed. Factor C4 doesn't correlate with LEAN factor. Hypotheses $\mathrm{H} 4$ was also confirmed by factors $\mathrm{C} 1$ and $\mathrm{C} 2$. As a consequence all but one factor correlate with the LEAN but only two of them independently. Hypotheses H5 was not confirmed because the determinant called "years of lean" doesn't change the model at all. 


\section{Conclusions}

The aforementioned verification of hypotheses generates some remarks regarding the findings. Firstly, the sample of secondary data tested is small and so it is not possible to speak of representativeness in statistical terms. Secondly, the research concentrated only on TPM stages paying little attention to strategy and any connection with personnel decisions (remuneration, training, etc.). Thirdly, the line managers, not the workers, observed the lean-oriented TPM practices and then were respondents of the research. Fourthly, a set of lean-oriented teamwork practices can change depending on the stage of lean requirements being used.

By answering the research questions we can say that: (1) 6 factors with 2-3 leanoriented TPM practices each were able to be developed, which (2) reflect the regular TPM model by Armstrong or Aguinis, with special attention on TPM supporting individual performance. In fact, we can talk about cyclic stages of planning, supporting and assessing team performance conducted by a manager, with special team responsibility for EPM. Only the characteristic features of practices are concentrated on lean requirements. Nevertheless, assessing individual performance goes against lean methodology. Moreover, (3) the LS requirements developed in the form of a single factor, (4) which in turn allowed us to show the influence of leanoriented TPM factors on the LS factor. Bear in mind that only two initial factors (prerequisite and planning performance of a team) independently influence the LS factor.

National culture indeed brings about problems for western rooted work teams to accept the Asian culture of lean methodology ${ }^{27}$. However, an interesting notion is that the performance management cycle corresponds exactly with Deming's PDCA tool, which makes it similar to a continuous improvement process ${ }^{28}$. There is still much room to broaden the investigating areas regarding the TPM - LS relationship and to concentrate on constraints which mainly derive from different work environments.

27 J.K. Liker, K. Ross, Droga Toyoty..., p. 362.

28 W.E. Deming, Out of the Crisis, Massachusetts Institute of Technology, Center for Advanced Engineering Study, Cambridge 1986. 


\section{References}

Aguinis H., Performance management, Pearson/Prentice Hall International, Harlow 2009.

Armstrong M., Armstrong's handbook of performance management. An evidence-based guide to delivering high performance, Kogan Page, New York 2015.

Atkinson C., Shaw S., Managing performance, [in:] R. Lucas, B. Lupton, H. Mathieson, (eds), Human Resource Management in an International Context, Chartered Institute of Personnel and Development, London 2006, pp. 173-198.

Borkowska S., Strategie wynagrodzeń, Oficyna Ekonomiczna, Kraków 2001.

Brumback G.B., Blending the "we/me" in performance management, "Team Performance Management: An International Journal" 2003, vol. 9, no. 7/8, pp. 167-173.

Chen J.C., Cox R.A., Value Stream Management for Lean Office - A Case Study, "American Journal of Industrial and Business Management" 2012, no. 2, pp. 18-21.

Chiarini A., Lean Organization: from the Tools of the Toyota Production System to Lean Office, Springer-Verlag Italia, Milan - Heidelberg - New York - Dordrecht - London 2013.

Deming W.E., Out of the Crisis, Massachusetts Institute of Technology, Center for Advanced Engineering Study, Cambridge 1986.

Den Hartog D.N., Boselie P., Paauwe J., Performance management; a model and research agenda, "Applied Psychology: An International Review" 2004, vol. 53, no. 4, pp. 556-569.

DeNisi A.S., Performance appraisal and performance management: a multilevel analysis, [in:] K.J. Klein, S.W.J. Kozlowski (eds), Multilevel theory, Research and Methods in Organizations, Jossey-Bass, San Francisco 2000, pp. 121-156.

Imai M., Gemba kaizen. Zdroworozsq̨dkowe podejście do strategii ciągłego rozwoju, Wydawnictwo MT Biznes, Warszawa 2018.

Liker J.K., Convis G.L., Droga Toyoty do lean leadership, Wydawnictwo MT Biznes, Warszawa 2012.

Liker J.K., Ross K., Droga Toyoty do doskonałości w ustugach, Wydawnictwo MT Biznes, Warszawa 2018.

Locher D., Lean Office and Service Simplified, CRC Press, Taylor and Francis Group, Boca Raton 2011.

Maurer R., Filozofia kaizen. Małymi krokami ku doskonałości, Wydawnictwo Helion, Gliwice 2016.

Pocztowski A., Zarzqdzanie zasobami ludzkimi. Strategie, procesy, metody, Polskie Wydawnictwo Ekonomiczne, Warszawa 2008.

Rothwell W.J., Graber J., McCormick N., Lean but Agile: Rethink Workforce Planning and Gain a True Competitive Edge, Amacom, American Management Association, New York 2012.

Shields J., Managing employee performance and reward. Concepts, Practices, Strategies, Cambridge University Press, Cambridge 2007.

Tapping D., The lean office pocket guide. Tools for the elimination of waste in the administrative areas, MCS Media Inc., Chelsea 2005.

Womack J.P., Why are rewards tied to individual performance so dangerous?, https://planet-lean. com/womack-rewards-metrics-yokoten/ (accessed: 7.07.2019). 


\section{Abstract}

The aim of this paper is to show the influence of lean-oriented team performance management (TPM) practices on lean service (LS) requirements within Polish service departments. To do this, it was necessary to identify how lean-oriented teamwork practices reflect the practices and stages of the universal TPM of selected authors. Exploratory factor analysis (EFA) by generalized least squares (GLS), Kaiser's normal varimax rotation methods and secondary data were used. The results reveal that lean-oriented TPM practices resemble universal TPM, and also that they help in the implementation of LS requirements, and the team has its share in managing individual performance.

Keywords: team performance management, lean service, practices, employee performance management 